\title{
Very Preterm Birth
}

National Cancer Institute

\section{Source}

National Cancer Institute. Very Preterm Birth. NCI Thesaurus. Code C121306.

Birth when a fetus is between 28 weeks and less than 32 weeks gestational age. 